\title{
Könyvszemle
}

SIPOS JÚLIA GONDOZÁSÁBAN

\section{AZ IDŐ SZEMIOTIKÁJA}

A kötetet a Magyar Szemiotikai Társaság 2017 őszén Egerben tartott konferenciájának előadásaiból állították össze. A szerkesztők huszonnégy előadás anyagát csoportosították öt fejezetbe. Erre az a konferenciacél adott lehetőséget, amely szerint a filozófiai, a pszichológiai, az (inter)kulturális, a nyelvi alapozottságú vizsgálatot egyaránt megengedhetőnek, sőt kívánatosnak tüzte ki, természetesen a szemiotika, a jelelmélet szempontjait érvényesítve. Erről a szerkesztők előszava szól.

Az idő alapfogalmai fejezetcím után olvasható Tolcsvai Nagy Gábor tanulmánya. A szerző szerint az emberi elme az általa feldolgozott időmúlást referenciapontokhoz kapcsolja. A mentális időfeldolgozások közösségi eredője a társadalmi idő rendszere, és a nyelvi szerkezetekben fejeződik ki. Az időt nem csupán jelöljük, hanem egyúttal jel is számunkra. Voigt Vilmos tanulmánya: Az óra (mint tárgy) szemiotikája. A régi időmérő megoldások szemiotikai értelemben az indexek csoportjába tartoznak (vagyis saját maguk jelei), ilyen az árnyékóra. A (mai, főleg díszítő célzatból elhelyezett) napórán is az árnyék mozgását használjuk. Az árnyék maga a jel. Az idő folyamatosságát jól mutatják a technikailag is folyamatos mozgású szerkezetek, például a vízióra (a görögség klepszüdrája), a homokóra. A mechanikai szerkezetek (óramúvek) a folyamatosság látványa helyett már számlapon mutatják az időegységeket. A számlapos rendszernek külön jelvilága van, a mutatók, a számok, a kör osztásrendje stb. révén mondhatni szemiotikai univerzum született. Szívós Mihály Az idö problémája a szemiotikai elemzésben címü dolgozata egyúttal a szemiotikai elemzés módszerét is taglalja. Csányi Gergely a freudi pszichoszexuális fejlődési szakaszokhoz visszanyúlva foglalkozik az időélmény ontogenetikájával.

Az idö és az ember összefoglaló cím alá Balázs Géza tanulmánya (Az idö szemiotikája) az időtlenségből jövő embertől a szakaszoló, mérő időérzékelésig tekinti át témáját. Terdikné Takács Szilvia a tér és az idő nyelvi és más ábrázolásának kérdéseiről ír. Gráfik Imre képekkel mutatja be az órás cégéreket, a cégek óráit mint jeleket. Ortutay Katalin az 1789-es francia forradalom új hónapneveinek mint időegységeknek históriáját mutatja be.

Az idő és a kultúra csoportjában először Büky László tanulmánya olvasható a Füst Milán-i költői nyelv időábrázolásáról, amelyben az 'éjszaka' a költő lehetséges világának fő ideje. Az előfordulások eloszlása Gauss-görbét mutat, vagyis 
nem természetes a szógyakoriság, hanem a költő nyelvének jeltulajdonsága. Újvári Edit a közép- és újkori képkompozíciók elemzésével mutatja be a keresztény időfelfogás megjelenítési módjait. Szirmai Éva az orosz mindennapi életben használatos ceŭчac 'mindjárt' szó időtartam-jelölési változatosságát tárja föl, a szó 'majd, idővel', 'most', 'sohanapján' és még több más szerepben jelenik meg a beszélői attitüdöt jelezve. Deák-Sárosi László az 1971-es Huszárik-film, a Szindbád időkezelésének, idősíkváltásainak technikai kivitelezését analizálja, azt is megmutatva, miként válnak szimbólummá az egyes képi megoldások.

$\mathrm{Az}$ idő és az információáramlás témakörében három dolgozat olvasható. Az információbiztonságban az eseménysürüség és az eseményklaszter értelmezése nélkülözhetetlen (Kollár Csaba). Az információfogyasztás a gyorsuló és lassuló időben címü dolgozat (Koltay Tibor) tárgya egyre többeket érint a világhálón (weben) az olvasás és információkeresés révén. Az idővel való gazdálkodást már az információs társadalom iskolájában kell (kellene?) megtanítani (Tomori Tímea).

Az idő és a nyelv mint befejező fejezet szerepel a kötetben. Pátrovics Péter szerint (Gondolatok az idő nyelvi képéröl) az idő legtöbbször megszemélyesítés formájában (eljár az idő) vagy eszközként, instrumentumként jelenik meg, ez utóbbira adott példái nyelvészetileg erősen kifogásolhatók. Pomozi Péter munkájában az igeidők vizsgálata révén a magyar múltidő-rendszer eredetének és leírásának újragondolásához igyekszik hozzájárulni. Kissné Rusvai Julianna a hantik időképének vázolásával a régi és a mostani állapotról tájékoztat. Utóbbi már nem a természethez közeli népre jellemző növény, állat, időjárás eseményein alapul, hanem az európai hónapmegnevezéseken. Dallos Edina tanulmányának tárgya az altaji sámánénekek időképe. A családnevek időbeli változásait Már Orsolya analizálja, egy háromszéki községben a 19. század végétől napjainkig, megállapítva, hogy a névszerkezet nem nagyon változott. Pölcz Ádám a retorikához tartozó időfogalmakat beszédfajták szerint jellemzi (például törvényszéki, bemutató, tanácsadó típusokat vesz föl).

A kötetet a szerzők néhány soros életrajza és e-mail-címe zárja, ez kétségkívül hasznos az ilyen rendkívül szerteágazó témakört tartalmazó kiadványban, mivel segítheti a kutatók személyes kapcsolatainak kialakítását vagy erösítését. Ez a szerteágazó témakör ugyanakkor egységes a szemiotikai alap tekintetében, hiszen a nyelv- és irodalomtudomány, a filozófia, a folklorisztika, a müvészetelmélet - amint a fenti vázlatos áttekintésből is kivehető - egyaránt alkalmazhatja a jeltudomány módszerét.

(Balázs Géza - Minya Károly - Pölcz Ádám szerkesztők: Az idő szemiotikája. [Magyar Szemiotikai Tanulmányok 43-44. - Semiotica Agriensis XVI.] Budapest: Magyar Szemiotikai Társaság, 2018, 285+3 o.) 